\title{
Urban tourism development in relation with shopping tourism Case study: City of Baneh
}

\author{
Ayoub Zoghi, Bakhtyar Khosravi* \\ Department of Geography, Payame Noor University, PO BOX 19395 - 3697, Tehran, Iran \\ *E-mail address: ayoubzohghi@yahoo.com
}

\begin{abstract}
The current research is written with the aim of identifying and explaining weakness, strength points, opportunities and threats facing tourism development of the city of Baneh, relation of urban tourism with shopping tourism and formulation of an optimal strategy using the SWOT strategic analysis. Today, tourism has become an important economic reality that exists in all places with peculiar qualities and attributes. Urban environments constitute the most important human environments that involve various facilities and infrastructure as well as main political, educational and recreational centers. These environments due to different attributes are visited by tourists. In the current research which is descriptive-analytical, by understanding weak and strength points, potentials and facilities of the city of Baneh, a strategic assessment of the Baneh's tourism with an emphasis on its relation with shopping was done whose results were a preparation of an aggressive strategy based on using the existing opportunities. Results suggest a strong trade zone with various goods that attracts many visitors from all over the country. However the most important problem is the inappropriate quality of communication roads and unofficial economy of this city which are considered as grave threats for the tourism economy of this city.
\end{abstract}

Keywords: Trade tourism; Shopping tourism; Urban tourism; Swot strategic model; Baneh city

\section{INTRODUCTION}

Of the most important issues that have resulted in recent development and growth of small and big cities is the urban development. Cities with services and facilities that provide have always embraced people, entering them. City with providing appropriate and favorable services, creates a ground for social, cultural and economic activities of humans. City also with providing services like hospitality and leisure facilities prepares a ground for tourism development and advancement (Timothy, 2005). Hence, cities have brought about new horizons for the urban development and the environment and this has been a main topic of interest for planners. Man lives and works in the city and city has always been a root cause of culture, history and art during different ages. In fact cities, are birth places of societies in a permanent perfection (Cravatte, 1997). As city activities change, urban forms and configuration changes too (Noorikermani, et al, 2010).

Efforts have been made to make city centers more interesting, causing in major environmental changes in them. These attempts have been made at first to fulfill the interests andneeds of the urban residents where the tourists too will enjoy welfare facilities. Thus, urban attractions play a main and dynamic role in the creation of urban tourism. The second 
assisting urban tourism inclination is the ever-increasing interests of the people towards cultural and national heritage and resources that are revealed by means of confluent phenomena like the success of large fairs and increased visiting level of treasures and historic cites (Frajirad et al, 2010).

Currently, urban tourism has become a symbolic and economic affair of main importance for most urban planners and officials that necessitates assessment, definition, and goal setting, choosing from among the choices in the area of investment and survey and creation of appropriate management structure as well asmakingurban tourism products tradable. Urban tourists as the users of urban environments by weighting and concentration on part of urban environments could be a considerable factor.

We already know that tourism industry affects the economic, social, cultural and environmental activities. Hence, tourism development and growth should be planned on a sustainable tourism development. Sustainable tourism development is a process that fulfills the current needs of the tourists and the society while supporting the need and enhancing its future (Farjirad, et al, 2010). Because, the host environment should be accountable to the needs of the visitors within the tourism affair and entrance of tourists to tourist places, appropriate infrastructure and facilities should be provided so that memory of visiting could lead to its repetition in later times.

On one hand, as tourists enter, the host environment will stand many pressures to accept the tourists' needs. On the other hand, the mission of urban managers and factors involved in tourism becomes greater. Following a strong pressure in recent decades by tourists exerted on most American and European cities like London, Paris, New York and Florence, a significant part of research centers both private and public has paid special attention to urban tourism. Urban tourism requires a set of theories, methods, and techniques for analyzing comparative studies and their development to understand the special role of cities inside tourism or tourism station in the urban forms and performance.

In new approaches to urban tourism, focus is to create performance links among urban centers and natural areas situated in the surrounding of cities so as to reduce negative consequences of the activities above on the urban environment and greater development is achieved, while expanding different service, welfare and communication infrastructures. Thus, we can through this channel fulfill sustainable tourism development and ecotourism. On this basis, a revision of literature sounds necessary (Noorikermani et al, 2009).

Baneh because of an appropriate situation resulting from being borderline with Iraq and by enjoying natural attractions, tourism, and many trade centers is considered to be of places with high potentials for tourism expansion, and shopping tourism in particular as well as trade tourism. Myriad natural attractions andexemplary tourism regions of this city in relation with border trade flourishing and many shopping centers, if proper and structural management is carried out, will embrace different groups of tourists. Because of an absence of efficient and basic planning, urban tourism has not expanded that much in this city, limiting the time duration of the tourists entering this city to one day shopping while if proper management is performed, and appropriate grounds as well as urban tourism infrastructure are established, this new industry could play a main role in expanding and promoting the station of the city of Baneh as a trade - tourist city in a future. 


\section{STATEMENT OF PROBLEM}

Urban regions because they have historic and cultural attractions, are often considered main tourism destinations. In addition to this, tourism attractions are situated in non- urban regions, since thecities offer services to their surroundings, they are in relation with tourism. Hence, a larger volume of tourism attractions is concentrated in cities so that tourism cities offer a consistent combination of land uses and economically speaking they emphasize on recreational activities in trade regions. In other words, tourist cities due to an accumulation of civil infrastructures could be thought of ideal places for tourists. There are many reasons for an expansion of tourism industry:

The first reason of tourism industry expansion in most countries is utilization of its economic interests, though there are other reasons concerning this. In Oh's view (2005), tourism could leave an important impact on increasing employment, revenues related to accommodation centers as well as government revenues. Hence, tourism affects the economic growth both directly and indirectly.

\section{A) Direct impact:}

Since tourism is one of the service industries, hence, the income resulting from this industry is thought to be a part of the gross domestic product that affects directly the economic growth of that region.

\section{B) Indirect impact:}

Tourism affects indirectly tourism because it shows dynamic impacts on the whole economy in form of influx effects or other externalities (Marin, 1992). If tourism because of high interaction with other economic activities flourishes, other economic activities that are offered to that good or service, will move along with it. In other words, tourism could act as an engine for the economic growth that will propel other activities along with itself .

On the other hand, economic growth impacts the tourism development . Economic growth, with an expansion of facilities and tourism infrastructure including development, transportation and roads, expansion of IT and communications, expansion of electronic money, expansion of accommodation centers, restaurants and hotels, expansion of public health sectors, and expansion of recreational facilities and welfare affairs has resulted in an expansion of tourism industry (Tayebi, et al, 2009).

Tourism can generate money because the money spent by people in the tourism centers will increase the income and as duties are imposed the taxation system of the country will be enhanced. Tourism could also leave positive and negative impacts on the environment. Using the revenue obtained from tourism, we can maintain and optimize or rebuild tourists accepting places. Entrance of passengers and tourists to any places will culminate in a generation of incomes and necessary budget will be achieved for maintaining historic sitesand the environment as a whole ( $\mathrm{G}$, Chak, 2003).

Along with the land uses related with the tourism sector and increased concentration and density of the cities, the need to other land uses including network of crossings and communications roads, and urban infrastructure facilities and installations will increase, thus, resulting in an extended urban structure. Thus, tourism could quicken the structural-spatial expansion. Generally, tourism can transform the city to another better place for life and support those urban characteristics to which citizens give importance.

To achieve these objectives, the urban universal perspective must replace few numbers of central sectors or in other words tourism traps. Additionally, investing in tourism must be aimed at improving the general perspective of the city and urban spaces while maintaining 
cultural and natural heritage. Tourism in addition to economic impacts, does have other cultural and social impacts (Hajinezad, et al, 2010).

In accordance with the potentials the city of Baneh has and a necessity felt for its development from a perspective of urban tourism with emphasis on tourism development, investigation of these potentials and discovery of the weak and strength points, opportunities and threats facing tourism will necessitate a preparation of an optima strategy in the form of this research.

In sum, it should be admitted that from among the objectives and goals of the tourists entering the city of Baneh, two goals are of high importance that determine the topic under investigation:

1. Urbana tourism and its related sub branches including trade tourism and shopping: These types of tourism activities are of high importance in the city and a high percentage of people entering the province of Kurdistan re concentrated in this area.

2. Ecotourism and activities related with nature tourism :A major part of natural attractions and recreational centers are located in the proximity of this city. Of which we can refer to natural lush woods surrounding the city and ecologic corridors of Baneh-saghes (Noorikermani, et al, 2009). The current research is written with the aim of identifying and explaining weakness, strength points, opportunities and threats facing tourism development of the city of Baneh, relation of urban tourism with shopping tourism and formulation of an optimal strategy using the swot strategic analysis. This research also attempts to investigate the shopping tourism which is of most important type of tourism and places great emphasis on the role and importance of shopping tourism and its relation with tourism development.

\section{Research objectives}

- Recognizing the facilities and obstacles of tourism development in Baneh

- Investigating an presenting appropriate guidelines to expand urban tourism

- Presenting a strategic model as well as fundamental strategies in accordance with potentials of tourism in Bane with emphasis on trade and shopping tourism

\section{Urban tourism}

Urban tourism means travel to another place with different motivations of seeing various attractions, urban facilities and sitesthat create motivation, interest and inclination in people. City is interesting for all ages. People are inclined to spend some off days in the city and have fun on vacations. Today, urban tourism has become an important activity that has resulted in extended spatial changes in big cities (Movahed, 2008, 33-34). Urban regions because of myriad cultural and historic at5ractions are oftentimes considered main tourism destinations. Cities have usually various and large attractions like museum s, memorable cites, theatres, sports clubs, parks, funfairs, shopping centers ,places with historic sites and districts related with main events with famous people that all in all attract people.

Along with tourism expansion in urban regions, more supportive services are built to meet the needs of tourists like restaurants and accommodation centers. Tourism infrastructure expansion contributes highly to the urban formation changes and the image of the city is overshadowed by these secondary services. Several characteristics of then cities are : 1. High physical density, 2. Playing different socio-cultural roles, 3. Playing different economic roles, 4. Objective centralization in intra city and regional networks. Activities of tourist in urban spaces, concerning attraction's, city structure, shopping, accommodation and secondary activities that are embodied in relation with recreational, cultural historic centers (Farajirad, et al, 2010). 


\section{Trade and business tourism}

The most important travels that take place under this title are :Travels that people go for participation in Makare markets, goods fairs, or visiting installations and factories. Participation in markets for exchange of goods and services will not only result in creation of buyers but also will make people have fun during their visit. Usually, in business related travels, accommodation is not optional and the costs of these travels are at the charge of trade companies. Increase of trade and business travels depend on the economic relation soft ye countries while the level of recreational travels is interrelated with the family expenses as well as travel incurred costs. Increased trade tourism is influenced by the reduced goods transportation fair and facilitation of traffic is of cases that flourishes tourism (www.ichto.ir).

Trade tourism which is created of trade conferences and fairs constitutes a major part of travels. Regarding trade tourism one has to say that this branch of tourism is of few branches that is not dependent on the season of holidays and for this it can increase the employment level of hotels in months that are not travel specific and number of passengers is few. Because Iran is located on the trade line of Middle Asia, port facilities, location of trade communications lines of Turkey with the east and locating on appropriate situation for entering to the markets of Afghanistan, Iraq, Middle Asia, it has an appropriate situation for utilizing tourism.

\section{Reasons why trade tourism matters}

Trade tourists usually have stopovers in on place and spend in the same place, generally $55 \%$ of trade tourists pay well for food and place. The most important trade characteristics is that though it is not related with tourism industry; trade prosperity results in a better understanding of economic activists concerning trade and industrial facilities as well as the tourism of the host country and this will provide a good ground for more investment.

\section{Shopping tourism}

It is one of tourism types created by means of purchase markets and variety of goods. This type of tourism has remained unknown in Iran in recent years and has not expanded that much. Purchase - oriented tourism is considered a factor for attracting tourists in most countries hosting tourists and tourism. Expansion of shopping centers are of measures that such countries as Turkey, China, Thailand and Malaysia call it as pivots of attracting tourists and they allot sums in their annual budgets for investment in this section.

However, in Iran markets and shopping centers due to goods purchase with high prices and lower quality contribute little to attract tourists and only handicrafts and souvenirs of any cut will attract tourists. This is in itself problematic because China has dominated the market of handicrafts, resulting in then destruction of Iranian handicrafts (Cultural heritage news press). However, domestically speaking this sort of tourism could be effective. Shopping tourists could because of a variety of goods and good prices as well as specialized markets in the area of goods variety flourish different areas. This has been seen in recent years in the city of Baneh. Given the material mentioned, this category needs organization and proper and fundamental management.

\section{Region under study}

Bane is located in the $270 \mathrm{~km}$ north western part of Sanadaj (Kurdistan center), in the 35 degrees and 59 minutes northern latitude and 45 degrees and 53 minutes eastern longitude towards the Greenwich meridian. This city leads to the heights between Saghes and Bookan from north, to Sardasht from the west north, to Saghes from east, to heights between Bane 
and Iraqi Kurdistan from south and to the Iraqi Kurdistan from the west (Najafi, 1990). The population of this city was 118667 in 2006 where from this number 74960 people were residing in the city and the rest were living in villages (Results of the public consensus and housing sector, 2006).

\section{METHODOLOGY}

The current research is descriptive-analytical and aims to find weak and strength points regarding the Baneh's tourism using the existing opportunities to deal with possible threats in order that an optimal strategy through the SWOT strategic model is prepared. The statistical population of the research is constituted by the tourists that enter in the city who have shopping and trade goals.

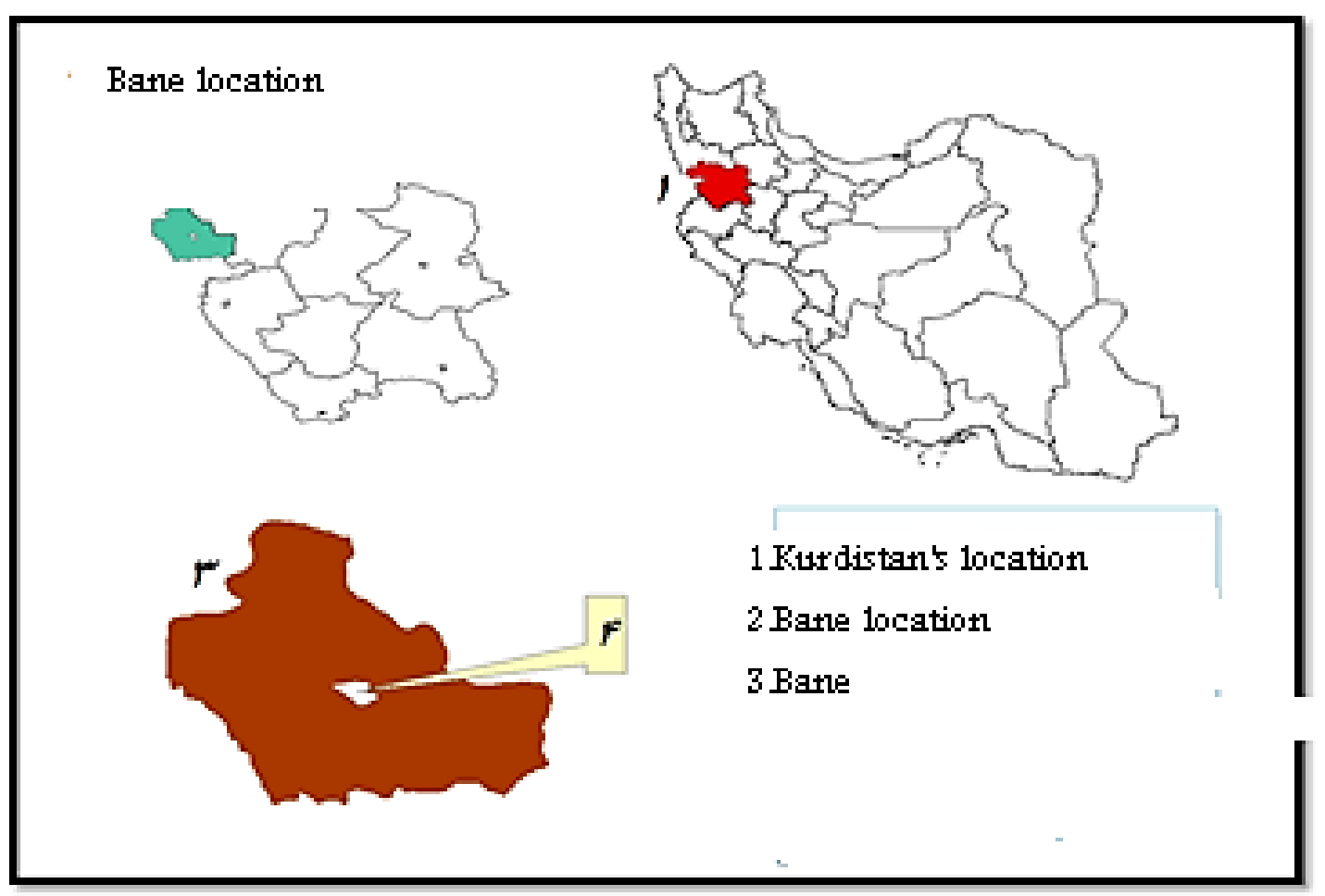

Figure 1. Location of Bane.

Baneh is one of the prosperous cities of Kurdistan that has become one of the trade centers of the province and the country as a whole because of proximity with Iraq. This city because is situated with the Iraqi borders has a good trade situation but problems such as slalom trade and lack of story parking lots as well as welfare centers in markets and also small streets have culminated in the fact that surrounding cities strive their best to attract gusts to their own cities. Much cheaper prices, various trade centers and their increase in the light of security governing the region, favorable climate and beautiful sights have all transformed Bnaeh to become one of the tourism poles of the country .

Borderline mini market of Seiranband is the second borderline mini market of the province and is situated in the $18 \mathrm{~km}$ of Bane. It started its operations in the first year of 
establishment as 600 vendors were working there who had become less than 80 as a result of weak financial affairs by the year 2002. However, despite a reduction in the number of people, the exchange trend and exports have had an ascending trend and given the fact that the mini market possesses a good potential for becoming one of the main trade centers as well as employment centers, officials should do more to protect it.

\section{Baneh's trade tourism characteristics}

Shopping and trade tourism are generally new types of tourism in Iran that are affected by situation $\mathrm{s}$, investments, and different characteristics of one place. Baneh as a borderline city with Iraq has flourished in recent tears so that it has expanded its influence range from north to Tabriz, from south to Khorramabad and Shahrekord and from eats to Tehran and Semnan. Goods entering to the city from the border are varied and for this trade and shopping tourism have grown.

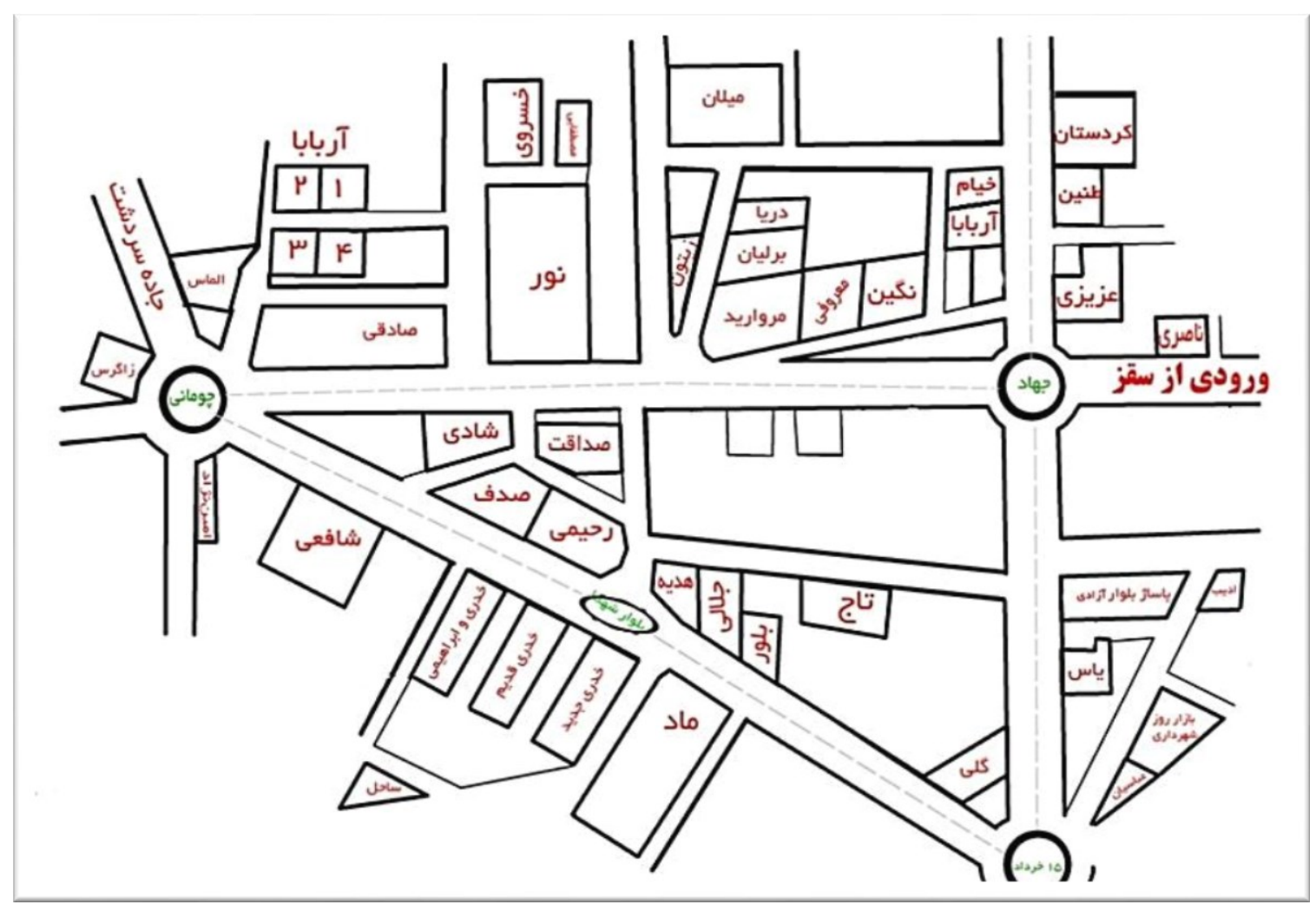

Figure 2. Location outline and number if shopping centers and passages in the city of Baneh 2012.

These goods enter the city mostly from border-unofficial exchanges and are sold in domestic markets and bazars. Thus, the Baneh economy is a trade economy which is considered to be the implication s of trade - border - exchange economy. Of reasons why unofficial trade and smuggling are on the rise is high number of unemployment, absence of fundamental infrastructure and facilities in order to produce and increase employment, lower public income and social inequalities, public poverty in borderlines, unfavorable quality of internally made goods in comparison to foreign made goods and the rule of consumption culture.

Affected by the 8 year old Iranian Iraqi conflict and operation of different groups and parties in the region, tourism and trade tourism in particular was in recent years stagnant. However, in recent years, an establishment of amicable relations between Iran and Iraq and 
also security policies adopted in the region, tourists are feeling more secure and as new border activities are increasing and goods are entering in the city officially and unofficially, trade exchanges are on the rise in such a way that trade complexes rose to 23 in 2007 from 1 in 1996 and to 44 in 2012 (Hajinezad, et al, 2009).

The average duration tourist stay is 1 to 3 days and the money spent by passengers is estimated from 100 to 200000 tomans (50 to 60 dollars roughly). Also the most important reason why people travel to Bane is for shopping and the most important cities sending tourists to Bane are outside provinces like Eastern and western Azerbaijans, Kermanshah, Zanjan, Tehran and Ghazvin (Hajinezad et al, 2010).

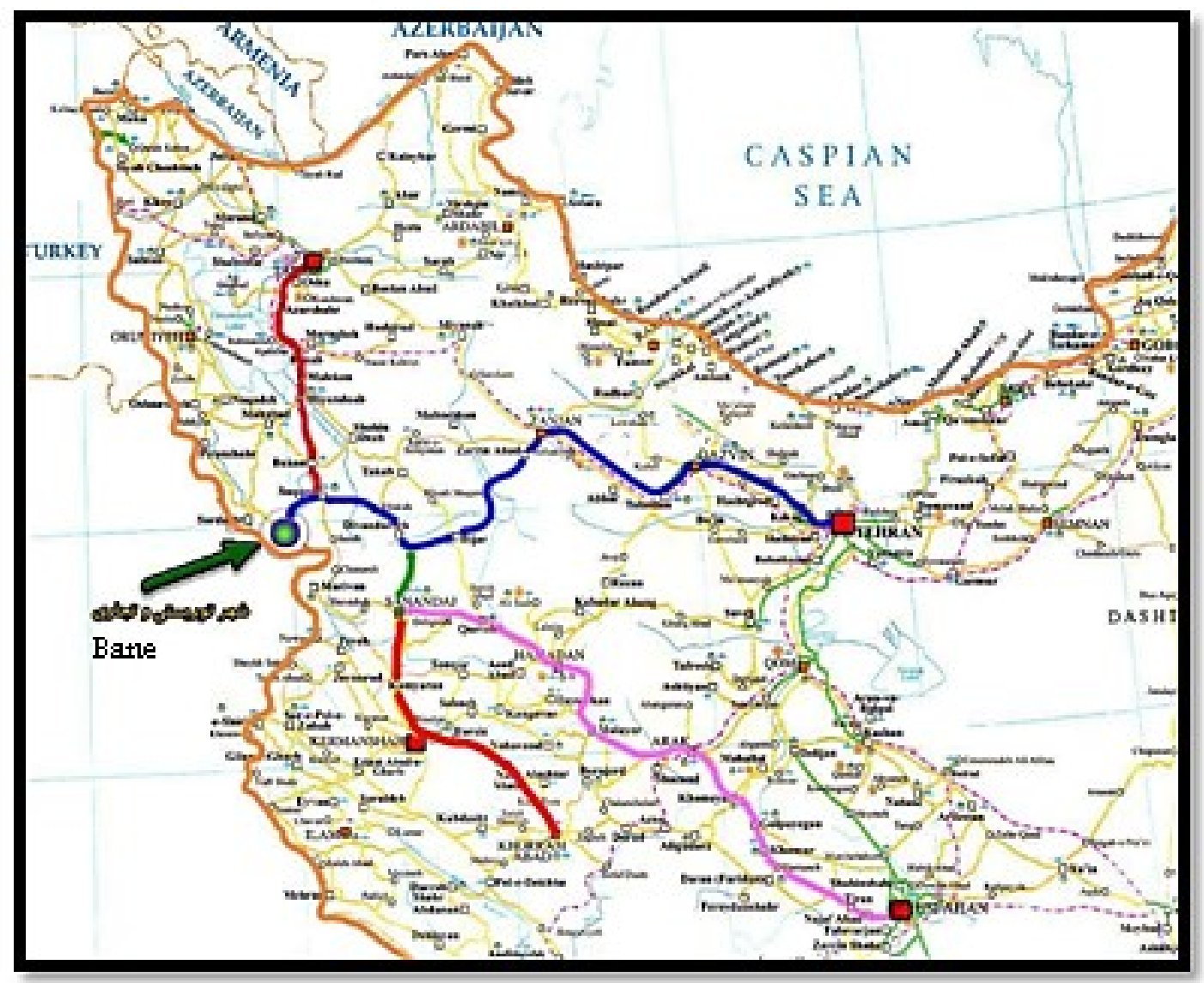

Figure 3. Communication roads leading to Baneh and its approximate influence range.

Along trade tourism of Bane, this city is rich in natural myriad sights and it is important from an ecotourism perspective. If fundamental management is done and appropriate infrastructure is created, this will increase the tourists' stay in the city and will render in the economic development of the city. Of these regions are seven sites like Aloot, Dukanan, Salook, Armorda, Sioorin, Boeeinsoflaand Nejne. 
Table 1. Number of tourist entering the city in 2005-2010.

\begin{tabular}{|c|c|c|c|c|c|c|}
\hline Year & 2005 & 2006 & 2007 & 2008 & 2009 & 2010 \\
\hline $\begin{array}{c}\text { No. } \\
\text { (person) }\end{array}$ & 25000 & 264000 & 568000 & 620000 & 680000 & 690000 \\
\hline
\end{tabular}

A report of tourists resident in this city in the year 2010 was 156698 people in accordance with the statistics of the Kurdistan's cultural heritage organization that signifies weaknesses in tourism sector to increase staying duration of tourists. This city includes 4 hostels and 2 hotels that do not meet the needs of all those tourists whatsoever. It should, be said that then 4 star hotel is under construction that could compensate for this shortfall.

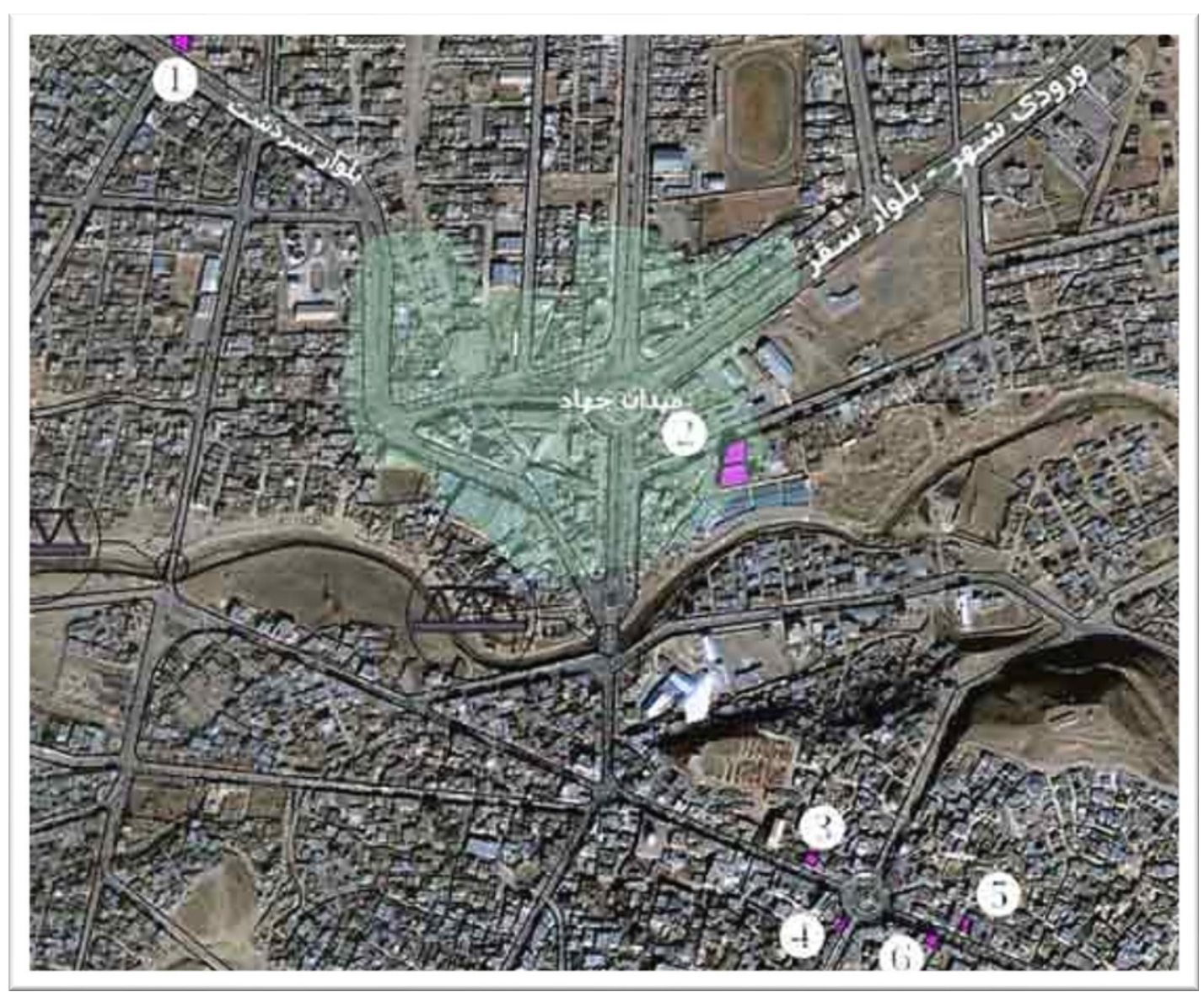

Figure 4. Hotel locations and hotels of Baneh.

\section{Measuring weak and strength points, opportunities and threats (SWOT)}

In order to present guidelines and policies of urban tourism expansion and a formulation of an appropriate strategy, understanding the four fold SWOT factors are inevitable to remove and eliminate weaknesses and threats and to improve strengths and opportunities. On this basis, in order to improve the performance of shopping tourism and trade tourism and formulation of a rational and appropriate strategy, we have listed weak and strong points to use the superiority of strong points and to reduce threats and weak points so that potentials and opportunities are applied to neutralize threats. The SWOT assessment is 
taken from a Harvard strategic model planning that is applicable in state or non -state sectors and simply refers to the fact that strategies effective on one organization are based on the capabilities. This strategy will utilize the benefits resulting from opportunities and situations, overcomes the weak points and minimizes the threats (Brison, 1996).

\section{Internal factors affecting the tourism development}

The aim of this stage is to measure the internal environment of the region under investigation form identifying weak and strong points i.e. aspects that are assisting or deterring in wake of accessing the objectives of planning and implementation of its assignments.

\section{External factors affecting tourism expansion}

The aim of this stage is to delve into the external environment of the range under investigation for identifying opportunities and threats where the region and organizations in relation with tourism expansion are facing.

Table 2. Internal factors affecting the tourism development.

\begin{tabular}{|c|}
\hline Strong points \\
\hline $\mathrm{S}_{1}$ - Various goods \\
\hline $\mathrm{S}_{2}$ - Strong trade zone with shopping malls and many passages \\
\hline$S_{3}$ - Many natural sights for tourists' visits \\
\hline $\mathrm{S}_{4}$ - Seiranband border mini market as official border with Iraq \\
\hline $\mathrm{S}_{5}$ - Sites and different ad-trade weblogs \\
\hline Weak points \\
\hline $\mathrm{W}_{1}$ - Urban economy dependence on the unofficial economy \\
\hline $\mathrm{W}_{2}$ - Entrance of goods through unofficial exchanges \\
\hline $\mathrm{W}_{3}$ - Cemyers being non-specialized and shopping malls \\
\hline $\mathrm{W}_{4}$ - Inappropriate situation of communication roads leading to Bane \\
\hline $\begin{array}{r}\mathrm{W}_{5} \text { - Lack of urban parking lots to prevent the throng of vehicles in the trade } \\
\text { center of the city }\end{array}$ \\
\hline $\mathrm{W}_{6}-$ Streets pollution and access located in the trade zone \\
\hline $\mathrm{W}_{7}-\mathrm{Weak}$ infrastructures appropriate for tourism \\
\hline
\end{tabular}


Table 3. External factors affecting tourism expansion.

\begin{tabular}{|c|} 
Opportunities \\
\hline $\begin{array}{c}\mathrm{O}_{1}-\text { Possibility of unofficial employment organization through expanding } \\
\text { tourism, accommodation and services sector }\end{array}$ \\
\hline $\begin{array}{c}\mathrm{O}_{2} \text { - Providing good grounds for formalizing the entrance of goods from the } \\
\text { border }\end{array}$ \\
\hline $\mathrm{O}_{3}$ - Creation of accommodation camps for the tourists \\
\hline $\mathrm{O}_{4}$ - Making shopping malls be specialized and devotion of each of the passages \\
to a special good
\end{tabular}

In a simplified analysis, by looking at weak, strong points and threats and opportunities, we can say that the threshold of vulnerability and weakness is down and using an optimal strategy and using the existing opportunities we can enhance the affecting factors and eliminate threats. 
Table 4. IFE Matrix (An assessment by the internal organization with emphasis on existing weak and

\begin{tabular}{|c|c|c|c|c|}
\hline SWOT analysis & $\begin{array}{c}\text { Initial } \\
\text { coefficient }\end{array}$ & $\begin{array}{l}\text { Secondary } \\
\text { coefficient }\end{array}$ & Ranking & $\begin{array}{c}\text { Final } \\
\text { coefficient }\end{array}$ \\
\hline \multicolumn{5}{|c|}{ Strong points } \\
\hline $\mathrm{S}_{1}$ & 326 & $0 / 23$ & 4 & $0 / 92$ \\
\hline $\mathrm{S}_{2}$ & 379 & $0 / 27$ & 4 & $1 / 08$ \\
\hline $\mathrm{S}_{3}$ & 261 & $0 / 18$ & 3 & $0 / 54$ \\
\hline $\mathrm{S}_{4}$ & 304 & $0 / 22$ & 3 & $0 / 66$ \\
\hline $\mathrm{S}_{5}$ & 143 & $0 / 1$ & 2 & $0 / 2$ \\
\hline Total & 1413 & 1 & & $3 / 4$ \\
\hline SWOT analysis & $\begin{array}{c}\text { Initial } \\
\text { coefficient }\end{array}$ & $\begin{array}{l}\text { Secondary } \\
\text { coefficient }\end{array}$ & Ranking & $\begin{array}{c}\text { Final } \\
\text { coefficient }\end{array}$ \\
\hline \multicolumn{5}{|c|}{ Weak points } \\
\hline $\mathrm{W}_{1}$ & & $0 / 15$ & & \\
\hline $\mathrm{W}_{2}$ & 265 & $0 / 14$ & 3 & $0 / 45$ \\
\hline $\mathrm{W}_{3}$ & 239 & $0 / 16$ & 2 & $0 / 28$ \\
\hline $\mathrm{W}_{4}$ & 290 & $0 / 17$ & 3 & $0 / 48$ \\
\hline $\mathrm{W}_{5}$ & 306 & $0 / 12$ & 4 & $0 / 68$ \\
\hline $\mathrm{W}_{6}$ & 218 & $0 / 12$ & 3 & $0 / 36$ \\
\hline $\mathrm{W}_{7}$ & 214 & $0 / 14$ & 2 & $0 / 24$ \\
\hline Total & 1785 & 1 & & $2 / 77$ \\
\hline
\end{tabular}

Table 5. EFE, matrix (An assessment by the external organizational sources based one existing opportunities and threats).

\begin{tabular}{|c|c|c|c|c|}
\hline SWOT analysis & $\begin{array}{c}\text { Initial } \\
\text { coefficient }\end{array}$ & $\begin{array}{c}\text { Secondary } \\
\text { coefficient }\end{array}$ & Ranking & $\begin{array}{c}\text { Final } \\
\text { coefficient }\end{array}$ \\
\hline \multicolumn{5}{|c|}{ Opportunities } \\
\hline $\mathrm{O}_{1}$ & 212 & $0 / 1$ & 3 & $0 / 3$ \\
\hline $\mathrm{O}_{2}$ & 320 & $0 / 15$ & 3 & $0 / 45$ \\
\hline $\mathrm{O}_{3}$ & 284 & $0 / 13$ & 4 & $0 / 52$ \\
\hline $\mathrm{O}_{4}$ & 303 & $0 / 14$ & 3 & $0 / 56$ \\
\hline $\mathrm{O}_{5}$ & 253 & $0 / 12$ & 3 & $0 / 36$ \\
\hline $\mathrm{O}_{6}$ & 219 & $0 / 1$ & 2 & $0 / 2$ \\
\hline $\mathrm{O}_{7}$ & 274 & $0 / 12$ & 2 & $0 / 24$ \\
\hline $\mathrm{O}_{8}$ & 314 & $0 / 14$ & 4 & $0 / 56$ \\
\hline Total & 2179 & 1 & & $3 / 19$ \\
\hline
\end{tabular}




\begin{tabular}{|c|c|c|c|c|}
\hline SWOT analysis & $\begin{array}{c}\text { Initial } \\
\text { coefficient }\end{array}$ & $\begin{array}{c}\text { Secondary } \\
\text { coefficient }\end{array}$ & Ranking & $\begin{array}{c}\text { Final } \\
\text { coefficient }\end{array}$ \\
\hline \multicolumn{5}{|c|}{ Threats } \\
\hline$T_{1}$ & 201 & $0 / 12$ & 2 & $0 / 24$ \\
\hline$T_{2}$ & 219 & $0 / 13$ & 3 & $0 / 39$ \\
\hline$T_{3}$ & 304 & $0 / 19$ & 4 & $0 / 76$ \\
\hline$T_{4}$ & 287 & $0 / 18$ & 2 & $0 / 36$ \\
\hline$T_{5}$ & 196 & $0 / 12$ & 2 & $0 / 24$ \\
\hline$T_{6}$ & 246 & $0 / 15$ & 2 & $0 / 3$ \\
\hline$T_{7}$ & 1638 & 1 & & $2 / 51$ \\
\hline$T_{0}$ &
\end{tabular}

Data obtained show that the existence of a strong trade zone with shopping malls and myriad passages with initial coefficient of 379 and the effect coefficient of 1/08 are thought to be main internal strong points.

Also tourists entering the city have considered the inappropriate communications roads leading to Baneh as the main weak point of this city on way of tourism development. If grounds are prepared to formalize the economy of the city, we can extend the relations with Iraq and flourish trade tourism as well as shopping malls without fearing the closure of the birders and stagnation of the markets.

\section{Comparative matrix formation and preparation of strategies}

SWOT matrix is one of the most important devices with which policy makers compare information related with internal and external factors and could via that design types of strategies necessary for their operations. These strategies are listed in a two dimensional SWOT table and each of the four parts of it signifies a type of strategy. These strategies are:

1. Aggresive strategies: Through this strategy, the strategist using the internal strong points tries to utilize external opportunities and to maximize opportunities by using strong points.

2. Revision or conservative strategy: The goal of this strategy is to use the existing opportunities in internal environment so that weak internal points are improved and promoted.

3. Defensive strategy: Organizations that apply this strategy are on the defense side and the aim of using this strategy is minimizing weak internal points and preventing threats resulting the external environments. In fact, such organizations attempt to reduce their activities to maintain their survival (Ceding or reduction strategy). They merge in other companies, file for bankruptcy and finally get dissolved.

4. Interactive or variety strategy: Strategists, implementing this guideline strive to reduce threats using the strong points. 


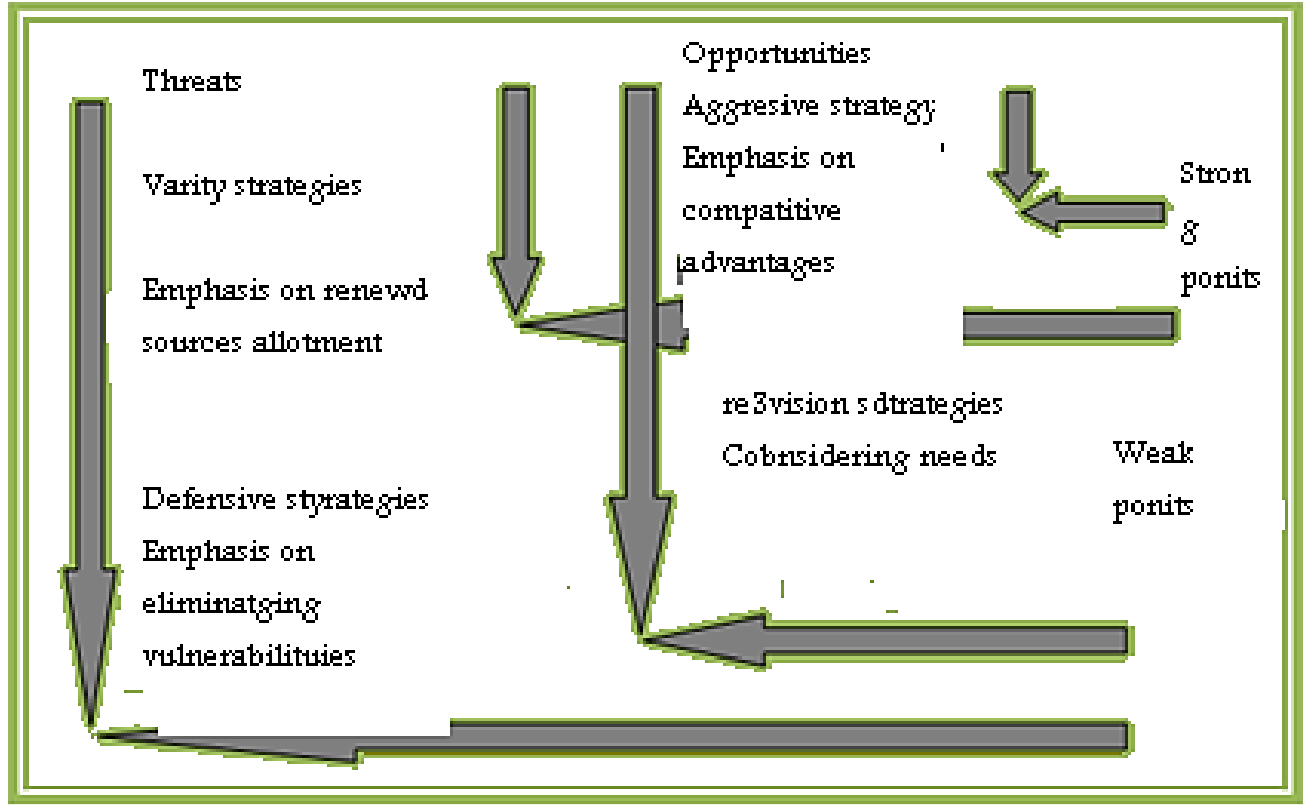

Figure 5. Methodological conceptual model for assessing the internal and external factors and determining the type of strategy.

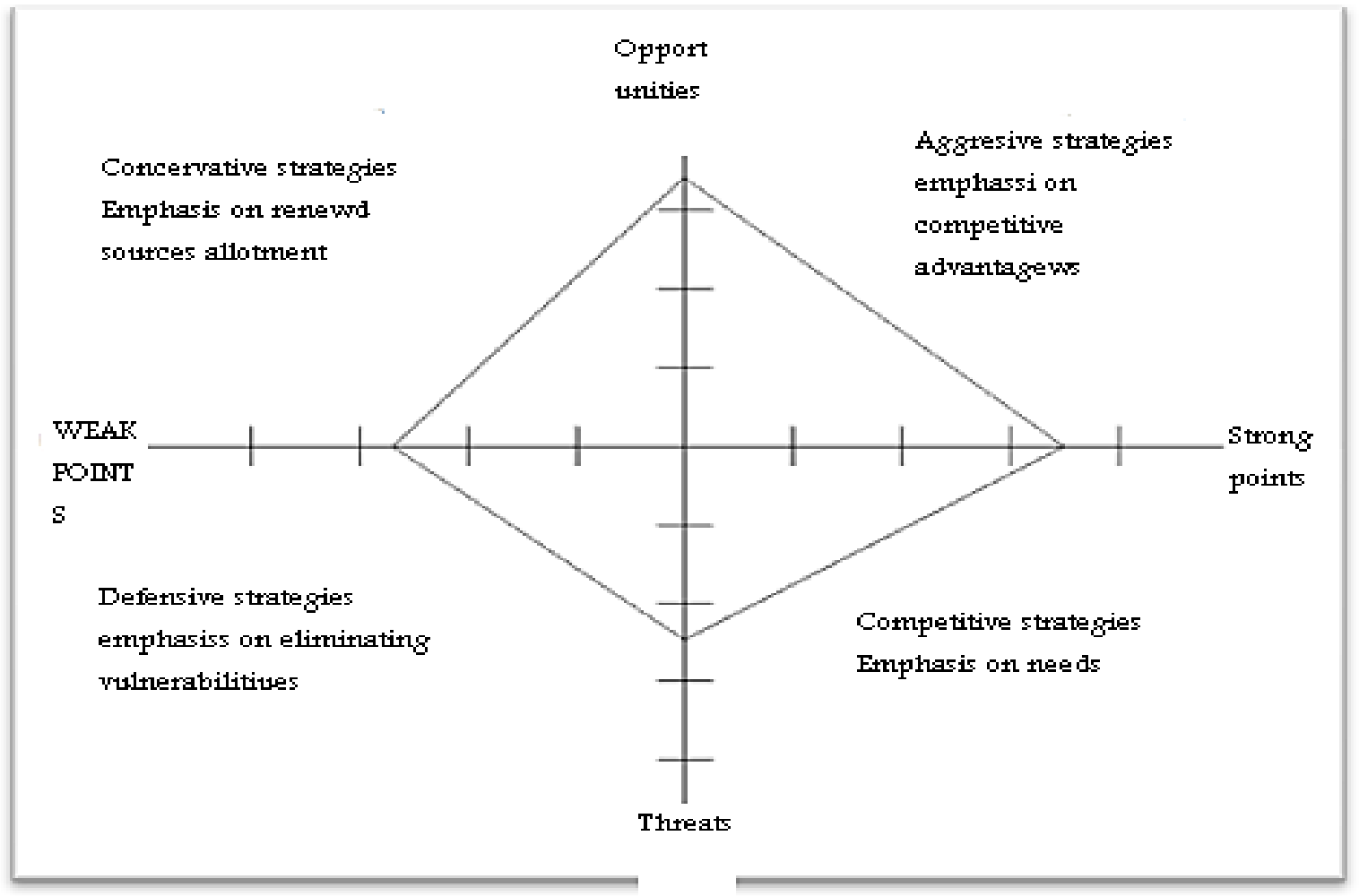

Figure 6. Final strategy of Baneh tourism expansion. 
On this basis, the strategy resulting from the SWOT analysis for tourism development of the city of Baneh with emphasis on shopping tourism of the aggressive strategy with emphasis on competitive advantages are matters under discussion where existing opportunities should be used to eliminate the threats (Figure 6).

On this basis, in accordance with the results obtained the final strategy of the Baneh urban tourism expansion is the aggressive strategy in the form of ancillary strategies which are:

- Making shopping malls specialized.

- Enhancing Seiranband mini market as the formal crossing of goods entrance to Bane.

- Encouraging different groups of people in Bane to import formal and permissible goods through incentive policies and exempt duties.

- Promoting roads leading to Baneh and quickening the establishment of Saghes airport.

- Enhancing natural tourism in line with urban tourism through infrastructure.

- Enhancing trade zone via public and private investment.

\section{CONCLUSIONS}

The current research is written with the aim of identifying and explaining weakness, strength points, opportunities and threats facing tourism development of the city of Baneh, relation of urban tourism with shopping tourism and formulation of an optimal strategy using the SWOT strategic analysis. Today, tourism has become an important economic reality that exists in all places with peculiar qualities and attributes. Urban environments constitute the most important human environments that involve various facilities and infrastructure as well as main political, educational and recreational centers. In accordance with the potentials the city of Baneh has and a necessity felt for its development from a perspective of urban tourism with emphasis on tourism development, investigation of these potentials and discovery of the weak and strength points, opportunities and threats facing tourism will necessitate a preparation of an optima strategy in the form of this research. Results indicate that trade centers and wholly the trade zone in Baneh is a main factor in expanding shopping tourism where on this basis fundamental planning should be done to promote this strategy.

\section{References}

[1] Brison John M. (1996). Planning for state and non-state organizations, Trans, by Abbas Monavarian, State education center publications

[2] Hjainezad Ali, et al, (2010), Effects of trade tourism on the spatial - structural development of the regions, case study, Baneh, Human geography research, No. 70, pp. 91-109.

[3] Cultural news press, 2010.

[4] Cultural heritage site of Kurdistan, 2010.

[5] Tayebi Seid Komeil et al., Journal of knowledge and development 24 (2009) 65-87.

[6] Frajirad Abdolreza, Zale Aseeri (2010). Analytical approaches to the sustainable urban tourism development, Periodical of land geography, No. 25 
[7] G. Chak (2004). International tourism, A universal perspective, Publications of culture and management, Tehran.

[8] Iran's statistics center, General statistics

[9] Movahed Ali (2007). Urban tourism, Ahvaz Shahid Chmaraan publications, First version.

[10] Najafi Yaghoob (1990). Kurdistan's general geography, Amir Kabir publications, Tehran.

[11] Noori Kkermani, Ayoub Zoghi, Arastoo Yarihesar, Masoud Alaee, Journal of research - scientific of the geography space, 2010, 137-156.

[12] Cravatte H. (1997). Introduction to historic town centers in the development of present - day towns, symposium, Strasbourg: council of Europe.

[13] Marin D., Review of economics and statistics 74 (1992) 678-688.

[14] Oh C. O., Tourism management 26 (2005) 39-44.

[15] Timothy d Allen J. (2005). Aspects of tourism, shopping tourism, retailing and leisure, channel view publications, Toronto.

[16] Marouf Emamgholi, Kaka Shahedi, Valeed Khaledian, Khaled Babaee, International Letters of Natural Sciences 4 (2014) 44-57.

[17] http://www.ichto.ir 